\title{
PENINGKATAN KETERAMPILAN BERBAHASA INDONESIA SISWA MELALUI VOICE NOTE SEBAGAI MEDIA DISKUSI
}

\section{IMPROVING STUDENTS' INDONESIAN LANGUAGE SKILLS THROUGH VOICE NOTES AS A DISCUSSION MEDIA}

\author{
Dwi Cahaya Nurani ${ }^{1}$, Agung Supardjo Budi Rahardjo² ${ }^{2}$ Fahmi Surya Adikara ${ }^{3}$ \\ ${ }^{1,2,3}$ STKIP Muhammadiyah Batang, Batang, Indonesia
}

Email :dcnurani@mbstkip.ac.id,agungliu22@gmail.com,fsadikara@mbstkip.ac.id

\begin{tabular}{l}
\hline Submitted \\
25 Desember 2021 \\
Accepted \\
07 Januari 2022 \\
Revised \\
20 Januari 2022 \\
Published \\
31 Januari 2022 \\
\hline
\end{tabular}

\section{Kata Kunci:}

Voice note;

Media diskusi;

Keterampilan

Berbahasa Indonesia;

Keyword:

Voice note;

Discussion media;

Indonesian Language

skills;

\section{Abstrak}

Tujuan penelitian ini adalah untuk meningkatkan keterampilan Berbahasa Indonesia siswa melalui penggunaan voice note pada platform Whatsapp sebagai media diskusi pada siswa kelas III SD Negeri Proyonanggan 01 tahun ajaran 2020/2021. Bentuk penelitian ini adalah penelitian tindakan kelas (PTK). Teknik pengumpulan data adalah observasi, wawancara, tes, dan dokumen. Validitas data adalah triangulasi sumber dan triangulasi teknik, serta validitas isi. Teknis analisis data adalah analisis interaktif, teknik deskriptif komparatif, dan teknik analisis kritis. Berdasarkan hasil penelitian dapat disimpulkan bahwa penggunaan voice note pada platform Whatsapp dapat meningkatkan keterampilan Berbahasa Indonesia Siswa. Peningkatan keterampilan Berbahasa Indonesia siswa tersebut dapat dibuktikan dengan meningkatnya nilai keterampilan Berbahasa Indonesia pada setiap siklus, yaitu nilai rata-rata keterampilan Berbahasa Indonesia siswa pada pratindakan hanya sebesar 69,8. Setekah mendapatkan tindakan di siklus I rata-rata kelas menjadi dan meningkat lagi pada siklus II menjadi 85,1. Pada siklus II siswa yang mencapai KKM sebanyak 30 siswa $(90,90 \%)$ dari jumlah siswa seluruhnya. Hal ini membuktikan bahwa indikator kinerja penelitian, yaitu ketercapaian KKM $\geq 75$ sebanyak $80 \%$ telah terpenuhi. Berdasarkan hal tersebut, dapat disimpulkan bahwa penggunaan voice note pada platform Whatsapp sebagai media diskusi dapat meningkatkan Keterampilan Berbahasa Indonesia siswa kelas III SD Negeri Proyonanggan 01 tahun ajaran 2020/2021.

\section{Abstract}

The purpose of this research in to improve indonesian language skills through voice note at platform Whatsapp as a discussion media in student III of State Primary School of Proyonanggan 01 in the academic year of 2020/2021. The form of this research is classroom action research (CAR). The data colecting technique was observation, interview, test, and documentation. The data validity was triangulation of resources and triangulation of technique, as well as the validity of the content. The analysis technique was interactive model, comparative descriptive techniques and techniques of critical analysis. Based on the results of the research, it can be concluded that using voice notes on the Whatsapp platform can improve students' Indonesian language skills. The improvement of students' Indonesian language skills can be proven by the increase in the value of Indonesian language skills in each cycle, namely the average score of Indonesian language skills of students before action only 69,8. After getting the action in cycle I the average class becomes and increases again in cycle II to 85,1. In cycle II students who achieved KKM as many as 30 students of the total number of students. Based on this, it can be concluded that the use of voice notes on the Whatsapp platform as a discussion media can improve the Indonesian Language Skills of grade III students of SD Negeri Proyonanggan 01 school year 2020/2021. 


\section{PENDAHULUAN}

Bahasa Indonesia merupakan mata pelajaran wajib yang harus diterapkan di tingkat Sekolah Dasar. Bahasa Indonesia menjadi materi pembelajaran yang sangat penting di sekolah. Melalui pembelajaran Bahasa Indonesia siswa akan diajarkan dan dilatih tentang keterampilan berkomunikasi, mengingat bahasa formal yang digunakan di Indonesia adalah Bahasa Indonesia. Menurut Intiana, dkk (2018) pembelajaran bahasa Indonesia selalu diarahkan untuk meningkatkan kemampuan berkomunikasi peserta didik. Kemampuan berkomunikasi ditentukan oleh keterampilan Berbahasa Indonesia siswa. keterampilan Berbahasa Indonesia di tingkat Sekolah Dasar meliputi mendengar (menyimak), berbicara, membaca, dan menulis. Menyimak dan membaca merupakan aspek reseptif, sementara berbicara dan menulis merupakan aspek produktif (Mulyati : 2015). Aspek reseptif bersifat penerimaan atau penyerapan, seperti yang tampak pada kegiatan menyimak dan membaca. Sementara aspek produktif bersifat pengeluaran atau pemroduksian bahasa, baik lisan maupun tertulis sebagaimana yang tampak dalam kegiatan berbicara dan menulis. Keempat aspek tersebut harus dikuasai oleh siswa sehingga tujuan pembelajaran Bahasa Indonesia, khususnya pada keterampilan Berbhasa Indonesia dapat tercapai. Salah satu Kompetensi Dasar Bahasa Indonesia di kelas III adalah menyajikan hasil pengamatan tentang keterhubungan antar gagasan ke dalam tulisan. Keadaan pembelajaran pada Kompetensi Dasar ini memerlukan keterampilan dalam membaca dan menuangkan kedalam bentuk tulisan. Pada masa pandemi seperti ini, pembelajaran dilaksanakan secara daring. Pernyataan ini merujuk pada pendapat Lestari dan Gunawan (2020) yang menyatakan bahwa proses pembelajaran di masa pandemi dilakukan dengan melaksanakan pembelajaran jarak jauh secara daring dari rumah masing-masing. Hal ini menjadi tantangan tersendiri bagi guru-guru dalam melaksanakan pembelajaran. Kendala dialami oleh guru dan siswa selama melaksanakan pembelajaram online (Nusantari, dkk : 2020).

Hasil pratindakan di Kelas III SD Negeri Pronoyanggan 01 tahun ajaran 2020/2021 mengenai keterampilan Berbahasa Indonesia menunjukkan hasil bahwa keterampilan Berbahasa Indonesia siswa masih rendah. Hal ini dapat dibuktikan dengan nilai rata-rata kelas siswa hanya 69,8 dan hanya ada satu siswa atau 3,03\% saja yang mencapai Kriteria Ketuntasan Minimal (KKM) sebesar 75. Sedangkan 32 siswa atau 96,97\% masih di bawah KKM. Hasil tersebut didukung dengan data hasil pbservasi awal mengenai keterampilan Berbahasa Indonesia yang mengungkapkan beberapa fakta. Fakta yang ditemukan di lapangan antara lain: 1) kemampuan siswa dalam memahami bacaan masih rendah 2) Hanya ada beberapa siswa yang dapat menggunakan Bahasa Indonesia yang baik dan benar 3) belum adanya penggunaan metode dan media pembelajaran yang sesuai untuk pembelajaran Bahasa Indonesia secara daring.

Fakta-fakta yang ditemukan di lapangan tersebut menjadi indikator bahwa keterampilan Berbahasa Indonesia siswa membutuhkan sebuah inovasi. Oleh karena itu, dalam upaya untuk meningkatkan keterampilan Berbahasa Indonesia siswa kelas III SD Negeri Proyonanggan 01 dipilih solusi untuk meningkatkan aktivitas dan partisipasi siswa dalam pembelajaran daring sehingga keterampilan Berbahasa Indonesia siswa dapat meningkat. Solusi tersebut adalah penggunaan voice note sebagai media diskusi dalam pembelajaran daring.

Penggunaan voice note pada platfform Whatsapp untuk media diskusi memungkinkan siswa untuk membaca dan mengungkapkan ide dan menjawab pertanyaan berdasarkan bacaan yang ada. 
Siswa dilatih berbicara menurut bahasa yang benar dan berusaha menyusun kalimat yang benar. Metode diskusi dengan voice note juga menambah kemampuan berpikir siswa untuk menuangkan kedalam kalimat yang dirangkai dan berbicara secara langsung. Menurut Widhiyasari, dkk (2019) dengan menggunakan WhatsApp, kita dapat melakukan obrolan online, berbagi file, bertukar photo dan lain lain. Penggunaan voice note yang ada dalam platform Whatsapp diharapkan mampu untuk meminimalisir permasalahan pembelajaran daring sehingga keterampilan Berbahasa Indonesia siswa dapat meningkat. Hasil penelitian yang dilakukan Iskandar (2020) menunjukkan bahwa penggunaan group Whatsapp sebagai media pembelajaran dapat membantu tutor dan siswa dalam proses pembelajaran.

\section{METODE}

Penelitian ini dilaksanakan di SD Negeri Proyonanggan 01. Subjek penelitian adalah guru dan siswa kelas III berjumlah 33 siswa. Waktu penelitian ini dimulai bulan Juli sampai bulan Desember 2020, tepatnya pada semester I tahun ajaran 2020/2021. Penelitian yang digunakan dalam penelitian ini adalah Penelitian Tindakan Kelas (PTK) dengan model siklus. Penelitian ini dilaksanakan dalam dua siklus, setiap siklus terdiri dari dua pertemuan dan setiap pertemuan terdiri dari empat tahapan, yaitu tahap perencanaan, tahap tindakan, tahap observasi, dan tahap refleksi.

Perencanaan yaitu menentukan pokok bahasan, membuat silabus dan Rencana Pelaksanaan Pembelajaran (RPP) dengan penggunaan Voice Note, menyusun lembar observasi guru dan siswa, serta, mengembangkan format evaluasi pembelajaran, dan menetapkan indikator ketercapaian yang dilaksanakan dalam proses pembelajaran. Tahap tindakan yaitu menerapkan penggunaan Voice Note dalam pembelajaran daring. Tahap observasi peneliti melakukan pengamatan terhadap guru, siswa, dan penggunaan Voice Note dalam pembelajaran daring. Tahap refleksi yaitu penilaian dan pengkajian terhadap hasil evaluasi data kaitannya dengan indikator kinerja tiap siklus.

Sumber data pada penelitian ini berupa sumber data primer, yaitu guru kelas dan siswa kelas III, serta sumber data sekunder yaitu observasi, wawancara, dokumen, dan tes. Validitas yang digunakan adalah triangulasi sumber dan triangulasi teknik, serta validitas isi. Teknik analisis data berupa model analisis interaktif, teknik deskriptif komparatif, dan teknik analisis kritis.

\section{HASIL DAN PEMBAHASAN}

\section{Hasil}

Sebelum pelaksanaan tindakan, peneliti melakukan tes untuk mengetahui kondisi awal, melakukan observasi, dan wawancara. Berdasarkan hasil kegiatan-kegiatan tersebut dapat disimpulkan bahwa nilai keterampilan Berbahasa Indonesia siswa tergolong rendah. Hal tersebut terbukti dari sebagian siswa masih belum mencapai $\mathrm{KKM} \geq 75$. Berdasarkan tes kondisi awal, didapati bahwa rata-rata kelas yaitu 69,8 . Siswa yang mencapai $K K M \geq 75$ hanya 1 siswa (3.03\%), sedangkan 32 siswa $(96,97 \%)$ belum mencapai KKM. Hal ini menunjukkan bahwa keterampilan Berbahasa Indonesia siswa masih sangat rendah.

Pelaksanaan keterampilan Berbahasa Indonesia pada siklus I dengan menggunakan voice note sebagai media diskusi menunjukkan adanya peningkatan. Hal ini terbukti dari adanya peningkatan nilai di siklus I. Hasil pelaksanaan siklus I menunjukkan bahwa siswa yang mencapai KKM $\geq 75$ sebanyak 15 siswa (45,45\%) dan siswa yang masih di bawah KKM sebanyak 18 siswa $(54,55 \%)$ dengan nilai rata-rata kelas yaitu 74,9. Indikator kinerja pada penelitian ini adalah jumlah siswa yang 
nilainya di atas $K K M \geq 75$ dapat mencapai $80 \%$ dari 33 siswa. Sehingga perlu dilakukan refleksi dan tindak lanjut pada siklus II.

Siklus II menunjukkan adanya peningkatan keterampilan Berbahasa Indonesia. Pada Tindakan di siklus II, siswa yang mencapai KKM $\geq 75$ meningkat menjadi 30 siswa $(90,90 \%)$ dari jumlah siswa seluruhnya, dan rata-rata nilai kelas menjadi 85,1 . Hal ini membuktikan bahwa indikator kinerja penelitian, yaitu ketercapaian KKM $\geq 75$ sebanyak $85 \%$ telah terpenuhi. Berdasarkan hal tersebut, tindakan yang diberikan selama penelitian dikatakan telah berhasil.

Data yang diperoleh berdasarkan kegiatan pratindakan, siklus I, dan siklus II kemudian dikaji dan dianalisis menggunakan model analisis interaktif, teknik deskriptif komparatif, dan teknik analisis kritis. Hasil analisis menunjukkan bahwa proses pembelajaran daring dengan menggunakan voice note sebagai media diskusi dapat meningkatkan keterampilan Berbahasa Indonesia. Selain itu, penggunaan voice note sebagai media diskusi dapat meningkatkan aktivitas siswa dalam pembelajaran daring.Peningkatan keterampilan Berbahasa Indonesia siswa kelas IIIA SD Negeri Proyonanggan tahun ajaran 2020/2021 dapat dibuktikan melalui perbandingan hasil keterampilan Berbahasa Indonesia sebelum dan sesudah dilakukan tindakan yang dapat dilihat pada tabel berikut:

Tabel 1. Data Perkembangan Nilai

\begin{tabular}{lccc}
\hline \multirow{2}{*}{ Keterangan } & \multicolumn{3}{c}{ Kondisi } \\
\cline { 2 - 4 } & Pra Siklus & Siklus I & Siklus II \\
\hline Nilai & 75,6 & 80,4 & 96,3 \\
Tertinggi & 64,6 & 71,8 & 73,5 \\
Nilai Terendah & 69,8 & 74,9 & 85,1 \\
Nilai Rerata & 3,03 & 45,45 & 90,90 \\
Ketercapaian (\%) & & \\
\hline
\end{tabular}

Pada pra tindakan hanya ada 1 atau 3,03\% siswa yang mencapai $\mathrm{KKM} \geq 75$ dengan rata-rata kelas 69,8. Hal ini menunjukkan bahwa keterampilan Berbahasa Indonesia di kelas IIIA SD Negeri Proyonanggan masih sangat kurang. Kurangnya pencapaian kompetensi tersebut disebabkan karena guru tidak menggunakan media audio dalam pelaksanaan pembelajaran daring, sedangkan pembelajaran hanya dengan menggunakan platform Whatsapp. Hal tersebut menyebabkan pembelajaran hanya berjalan satu arah saja sehingga keterampilan Berbahasa Indonesia siswa masih kurang.

Setalah diberikan tindakan pada siklus I, sebanyak 15 siswa atau 45,45\% mendapat nilai di atas KKM dengan rata-rata kelas 74,9. Peningkatan rata-rata nilai kelas tersebut belum mencapai indikator kinerja penelitian. Hasil refleksi siklus I adalah meskipun sudah menggunakan voice note sebagai media diskusi, guru masih mendominasi kelas dan kurang memberi motivasi kepada siswa. Selain itu, beberapa siswa belum terampil dalam menggunakan fitur voice note. Hasil refleksi tersebut digunakan sebagai dasar pengembangan pembelajaran daring pada siklus II dengan menerapkan upaya-upaya perbaikan.

Tabel 1 menunjukkan bahwa indikator penelitian sudah tercapai pada siklus II. Hal tersebut dibuktikan dengan peningkatan nilai dan rerata kelas. Siklus II menunjukkan sebanyak 30 siswa atau $90,90 \%$ mencapai $\mathrm{KKM} \geq 75$ dengan rata-rata kelas mencapai 85,1. Indikator kinerja penelitian dapat tercapai pada siklus II karena guru dan siswa telah melaksanakan pembelajaran daring yang menggunakan voice note sebagai media diskusi dengan baik dan mampu mengatasi permasalahan yang terjadi pada siklus I, sehingga pembelajaran daring dapat terlaksana secara efektif dan efisien. 


\section{Pembahasan}

Pencapaian indikator kinerja penelitian dan pencapaian kompetensi siswa menunjukkan bahwa penggunaan voice note sebagai media diskusi dalam pembelajaran daring dapat meningkatkan keterampilan Berbahasa Indonesia siswa. Voice note dapat dimanfaatkan untuk meningkatkan keaktifan siswa ketika pembelajaran dilaksanakan secara daring dengan platform Whatsapp sehingga keterampilan Berbahasa Indonesia siswa dapat meningkat. Hal ini sejalan dengan hasil penelitian yang dilakukan oleh Widhiyasari, Umami, \& Suja'i (2019) yang menyatakan bahwa ada pengaruh penggunaan media sosial Whatsapp terhadap keaktifan siswa.

Saat ini dunia pendidikan menuntut guru untuk mengajar dengan media komunikasi dua arah yang kreatif dan inovatif (Peng dan Shashipriya Nadaraja, 2014). Voice note memungkinkan guru dan siswa melakukan pembelajaran dua arah saat melaksanakan pembelajaran secara daring. Pembelajaran dua arah dapat membangun suasana kegiatan belajar-mengajar menjadi lebih menyenangkan Ketika pembelajaran dilaksanakan secara daring. Hal ini diperkuat oleh pendapat Putra \& Nisaurrasyidah (2020) menyatakan bahwa voice note dapat digunakan sebagai forum diskusi, yaitu tempat untuk mewadahi aktifitas tutor dan warga belajar, dimana dalam forum diskusi tersebut tutor dan warga belajar dapat terlibat dalam komunikasi dua arah. Guru membuat topik yang akan didiskusikan kemudian dikomentari dan didiskusikan bersama-sana oleh siswa. Penggunaan voice note memfasilitasi siswa untuk mengungkapkan pendapat daalam pelaksanaan diskusi dengan menggunakan Bahasa Indonesia yang baik dan benar. Ketika siswa terbiasa untuk mengungkapkan pendapat maka siswa keterampilan berbahasa siswa akan semakin baik.

\section{SIMPULAN DAN REKOMENDASI}

Berdasarkan berbagai data yang telah diperoleh, mulai dari sebelum tindakan dan data dari tindakan yang dilaksanakan dalam siklus I dan siklus II, maka dapat disimpulkan bahwa melalui penggunaan Voice Note sebagai media diskusi dapat meningkatkan keterampilan Berbahasa Indonesia pada siswa kelas III SD Negeri Proyonanggan 01 tahun ajaran 2020/2021. Peningkatan keterampilan Berbahasa Indonesia pada siswa kelas III SD Negeri Proyonanggan 01 tahun ajaran 2020/2021 dibuktikan dengan nilai rata-rata siswa pada pratindakan hanya sebesar 69,8 menjadi 74,9 pada siklus I dan meningkat lagi menjadi 85,1 pada siklus II.

Berdasarkan hasil penelitian yang telah dilakukan maka diajukan saran dalam penggunaan voice note sebagai media diskusi, harus dipastikan bahwa siswa sudah dapat menggunakan fitur voice note dengan baik. Selain itu butuh adanya kerjasama dan pendampingan oleh guru dan orang tua sehingga siswa dapat fokus mengikuti pembelajaran. Peneliti lain dapat mengembangkan penggunaan voice note pada materi yang lainnya dan jenjang kelas yang berbeda, artinya tidak hanya diterapkan di kelas III saja dengan memperhatikan Kompetensi Dasar yang harus dicapai oleh siswa.

\section{DAFTAR PUSTAKA}

Intiana, S.R.H., Sapiin, \& Suyanu. (2018). Peningkatan Keterampilan Berbahasa Indonesia Dengan Metode Pemodelan Berpola Lesson Study pada Siswa Kelas XI SMA Negeri 1 Labuapi. Jurnal Mabasindo, 2 (2), 74-86.

Mulyati, Yeti. (2015). Keterampilan Berbahasa Indonesia SD. Jakarta Universitas Terbuka.

Lestari \& Gunawan. (2020). Implementasi Pembelajaran Jarak Jauh Selama Pandemi Covid-19 di SD IT Al- Huda Wonogiri. Skripsi Tidak diterbitkan. Surakarta: Fakultas Keguruan dan Ilmu Pendidikan Universitas Muhammadiyah Surakarta. 
Nusantari, S.S., Sumarwati, Anindyarini, A. (2020). Pembelajaran Bahasa Indonesia Secara Online pada Masa Pandemi Covid-19 di SMA Islam Terpadu Nur Hidayah Sukoharjo. Jurnal Basastra: Jurnal Bahasa, Sastra, dan Pengajarannya, 8 (2), 206-214.

Widhiyasari, M., Umami, N., Suja'i, I.S. (2019). Pengaruh Penggunaan Media Sosial Whatsapp Terhadap Keaktifan Siswa pada Mata Pelajaran Ekonomi Bisnis Kelas X SMK Negeri Boyolangu Tahun Ajaran 2018/2019. Jurnal Pendidikan Ekonomi, 12 (2), 94-98.

Iskandar, R. (2020). Penggunaan Grup Whatsapp Sebagai Media Pembelajaran Terhadap Peserta Didik DTA At-Tawakal Kota Bandung. Jurnal Comm-Edu, 3 (2), 97-101.

Peng, C. F. \& Shashipriya Nadaraja. (2014). Pelaksanaan Pelaksanaan Kemahiran Berfikir Kreatif Dan Kritis Dalam Pengajaran dan Pembelajaran Komsas Di Sekolah Menengah. Jurnal Pendidikan Bahasa Melayu.

Putra, N.P. \& Nisaurrasyidah, I. (2020). Solusi Pembelajaran Jarak Jauh Menggunakan Aplikasi Zoom dan Whatsapp Group di Era New Normal pada Warga Belajar Paket C di PKBM Bina Mandiri Kota Cimahi. Prosiding Webinar Magister Pendidikan Nonformal UNG: Pembelajaran Anak Usia Dini berbasis Sentra Alam dengan Pendekatan saintifik pada masyarakat Teluk Tomini, 19-24. 